\title{
Rare dune plant species in Samsun Province, Turkey
}

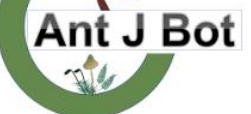

Received : 10.04.2019 Accepted : 25.06.2019 Online : :27.06.2019

\author{
Burak SÜRMEN ${ }^{1}{ }^{*}$, Şenay ULU AĞIR ${ }^{2}$, Hamdi Güray KUTBAY $^{\mathbf{D}}$ \\ ${ }^{1}$ Karamanoğlu Mehmetbey University, Kamil Özdă̆ Science Faculty, Department of Biology, Karaman, Turkey \\ ${ }^{2}$ Ondokuz Mayls University, Science and Arts Faculty, Department of Biology, Samsun, Turkey \\ *buraksurmen@gmail.com
}

\section{Samsun (Türkiye) İli’ndeki nadir kumul bitki türleri}

\begin{abstract}
In the present study, the rare species of the city Samsun which distributed in sand dune ecosystem were investigated The study was carried out in the localities Cobanyatağ 1 (Terme), Sindel, Hürriyet and Costal (Carşamba), Cernek, Sahilkent (Bafra) and Doyran (Alaçam) of Samsun sand dune. Sand dune communities were sampled from April 2010 to July 2012 by using minimal area method in $16 \mathrm{~m}^{2}$ plots. The coastal sand dunes of Çobanyatağı, Sindel, Cernek, Sahilkent (Bafra) and Doyran (Alaçam) is consist of upper beach/driftline, primary/embryonic, main, transitional and, fixed dune zones ) while the fixed zone is totally disappeared and transitional zone is significantly interrupted in the localities Costal and Hürriyet especially due to the building settlement. Rare species on each coastal dune zones in all localities were determined according to the rarity index formula. As a result, each locality was assessed independently, and it is indicated that the rarity index of 47 species is low.
\end{abstract}

Key words: Black Sea, Coastal habitats, Rarity index

Özet: Bu çalışmada Samsun ilinde kumul ekosistemlerde yayılış gösteren nadir türler araştırılmıştır. Araştırma Samsun kıyısında Çobanyatağı (Terme), Sindel, Hürriyet ve Costal (Çarşamba), Cernek, Sahilkent (Bafra) ve Doyran (Alaçam) lokalitelerinde yürütülmüştür. Kumul komuniteleri Nisan 2010'dan Temmuz 2012'ye kadar, en küçük alanlar metodu kullanılarak $16 \mathrm{~m}^{2}$ lik örnek parseller şeklinde örneklenmiştir. Çobanyatağı, Sindel, Cernek, Sahilkent ve Doyran lokalitelerinde üst kumsal (sürüklenme çizgisi), primer kumul, esas kumul, geçiş kumulu ve stabil kumul zonlarından oluşurken, Costal ve Hürriyet lokalitelerinde ise özellikle yerleşim alanlarının açılması nedeniyle stabil kumul zonu tamamen yok olmuş, geçiş zonu da önemli derecede kesintiye uğramıştır. Nadirlik indeks formülü ile her lokalitede bulunan zonların nadir türleri belirlenmiştir. Sonuç olarak her bir lokalite bağımsız olarak değerlendirilmiş ve nadirlik indeks formülüne göre 47 türün nadirlik indeksinin düşük olduğu tespit edilmiştir.

Anahtar Kelimeler: Karadeniz, Kıyı habitatlar, Nadirlik indeksi

\section{Introduction}

Coastal dune ecosystems are located in a very narrow area on earth, but they have the highest biodiversity compared to other ecosystems (Carranza et al., 2008). Dune ecosystems are habitat with their specific plant species, vegetation types and highest endemism ratio and local biodiversity values (Honrado et al., 2010). Many sand dune plants can not survive except for coastal dune habitats. Especially in recent years, due to the increasing anthropogenic factors, very sensitive coastal dune areas suffer damage, and they are under threat of extinction. So, many plant species in coastal dunes face to extinction (Ağır et al., 2014, 2016a; Kutbay et al., 2017)

The coastal dunes which are dynamic structures are the transition (ecotone) regions between terrestrial and aquatic ecosystems (Acosta et al., 2005; Carboni et al., 2009; Miller et al., 2010). The dune ecosystems gain a complex structure as a result of the effects of environmental factors towards the inner parts (A $\breve{g} ı r$ et al., 2016b, 2017). This complex structure leads to the change of the dune morphology and consequently to the inclusion of different plant communities (Attore et al., 2013; Prisco et al., 2012), and causes differences in the spatial distribution of the dune plants (Attore et al., 2013). In the protected coastal dunes, vegetation is hardly associated with geomorphological and sedimentological characterization (Fenu et al., 2012).

The coastal dunes are a natural barrier against the spread of saltwater and wind erosion (Spanau et al., 2006).
Coastal dune vegetation plays an important role in dune stabilization. Therefore, the loss of plant species in the dune vegetation makes the dunes permeable to wind and wave erosion (De Lillis et al., 2004). Sand dunes, which are sensitive to wave erosion, play an important role in maintaining the sediment balance (Ağır et al., 2017). However, climate change and anthropogenic effects disrupt the natural structure of the dune vegetation (A $\breve{g} ı r$ et al., 2016b). These factors cause narrowing of the distribution areas of the plants in the dune areas and thus cause the extinction of the plant species (Stancheva et al., 2011). For this reason, new studies should be carried out in these areas in order to determine the biodiversity and conservation procedures of these areas (Carranza et al., 2008).

The aim of the present study is to determine the rarity indexes of coastal dune plant species for each dune zone. So we reveal the latest status of plant species in studied coastal dune area.

\section{Materials and Method}

The research area which includes both Gölardı Nature Conservation Area (Terme) and, Cernek Lake Wildlife Protection Area (Bafra), covers $149 \mathrm{~km}$ of coastline in Samsun from Terme to Alaçam. Seven localities which include characteristic dune zones [upper beach or drift line (A), embryonic or primary dune (B), main dune (C), transitional (D) and fixed dune (E) zones] (Figure 1) were chosen. 


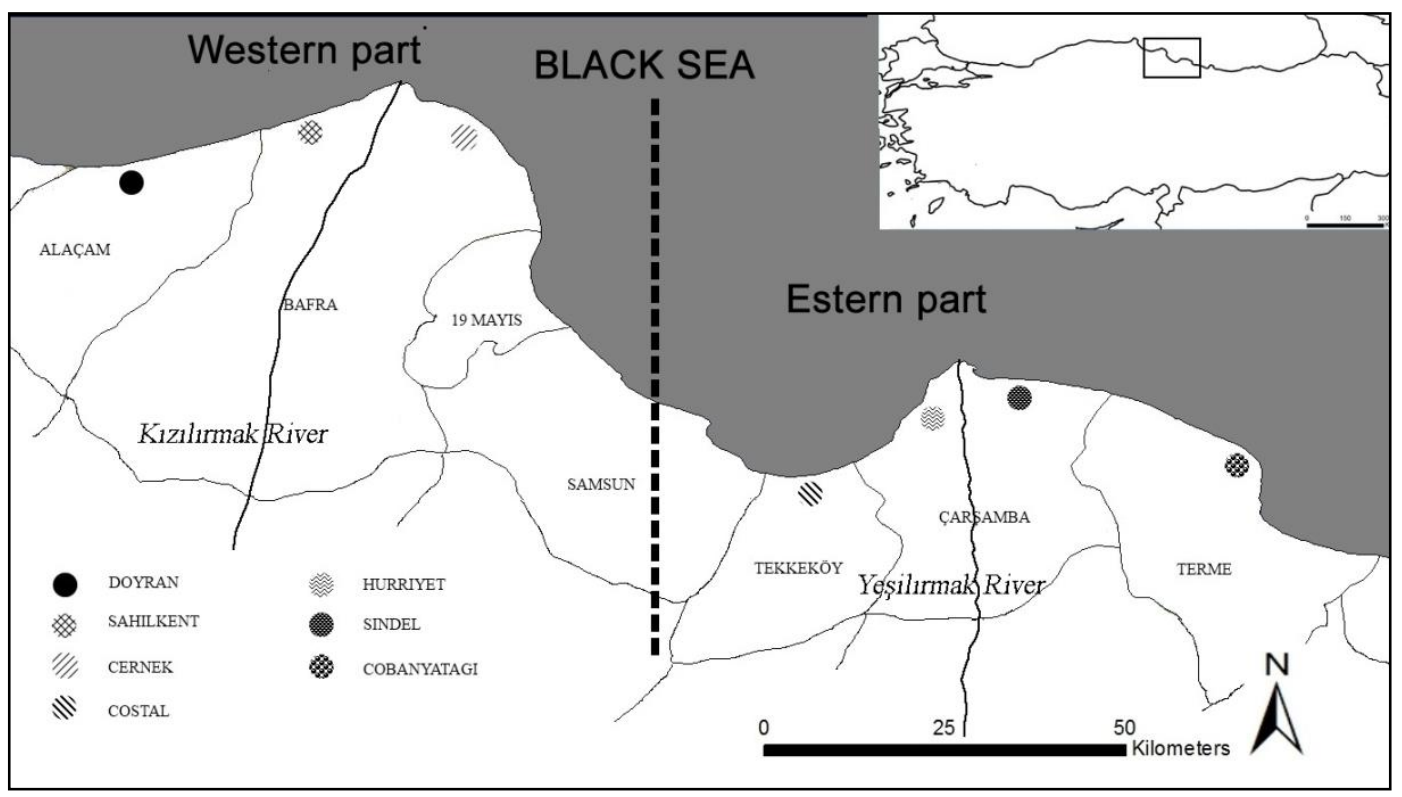

Figure 1. Localities of the research areas.

Seven vegetation plots were chosen from each locality and each zone. Plot size was determined by minimal area method. $4 \times 4 \mathrm{~m}^{2}$ plots were choosed from each communities of the vegetation zonation: upper beach or drift line, embryonic dune, main dune, transition and fixed dune zones from homogenous places in April-September 2010-2012. The vascular plant list and cover value of each species in all plots were registered according to BraunBlanquet method (Braun-Blaunqet, 1964).

Taxonomic nomenclature was followed according to Guner et al. (2012).

The species rarity index formula has been developed from the rarity index formula used for sample plots (Acosta et al., 2009).

$$
S_{j}=\frac{\left(\frac{\sum_{i} I_{j k}}{N}\right)\left(\frac{N_{j}}{N}\right)}{10}
$$

$\mathrm{Sj}$ : presence coefficient of i species (between 0 and 1). If " $\mathrm{Sj}$ " is close to 0 , species is rarely. If " $\mathrm{Sj}$ " is close to 1 , species is abundant. $\sum_{\mathrm{i}} \mathrm{I}_{\mathrm{jk}}$ : Total density of $\mathrm{J}$ species in all sample plots. $\mathrm{N}$ : Total sample plots. $\mathrm{Nj}$ : Number of sample plots with $\mathrm{J}$ species. 10: fixed number (to be between 0 and 1 ). $\mathrm{Sj}>0.05$ (no rarely), $0.01<\mathrm{Sj}<0.05$ (moderate rarely) and $\mathrm{Sj}<0.01$ (very rarely) ranges were used for the detection of rare species.

\section{Results}

Sixty-seven coastal dune character species were determined. The distribution of character species which is given in Table 1. 11 species in upper beach or drift line dune (A) zone, 18 species embryonic or primary dune (B) zone, 9 species the main dune (C) zone, 9 species transitional (D) dune zone, 20 species in fixed dune (E) zone were determined. Also, floristic regions, growth forms and life spans of the species were determined.

Plant species belonging to five floristic regions, IranoTuranian, Euro-Siberian, Mediterranean, South America and Paleo Temporal, were determined in the study area of coastal dune vegetation.

Seven species of upper beach or drift line dune zone belong to a floristic region (Irano-Turanian, EuroSiberian, Mediterranean, South America, and Paleo Temporal) while four species do not belong to any floristic region. Ten species were herbaceous, only Tournefortia sibirica L.var. sibirica was shrub. The life span of five species were annual while the others are perennial (Table 1).

Most of the species of the embryonic or primary dune zone, belong to the Mediterranean floristic region while two of them, Agrostis stolonifera L. and Hypochoeris radicata L. were Euro-Siberian floristic elements, and only Gundelia tournefortii L. was Irano-Turanian floristic element. 17 species were herbaceous, and only Medicago marina L. was shrub species (Table 1).

In the main dune zone, Cionura erecta (L.) Griseb., Euphorbia peplis L. and Vulpia fasciculata (Forsskal) Fritsch were Mediterranean elements. Echinops orientalis Trautv. was Irano-Turanian element and Xanthium spinosum L. was South America element. Many of species were annual, and one species was shrub (Table 1).

In transitional dune zone, four species belong to EuroSiberian, Mediterranean and Paleo Temporal floristic regions. There are one tree and shrub species in this dune zone. The other plants were herbaceous. Two species were annual, and seven species were perennial (Table 1).

The fixed dune zone was the richest zone in all zones about plant species with 20 plant species. Seven species were Mediterranean floristic elements, four species were Euro-Siberian floristic elements and only Trifolium arvense L. var. arvense was Paleo Temporal floristic element. Many species have got herbaceous growth form, and only Jurinea kilaea Azn. was shrub species. Seven species were perennial, and 13 species were annual (Table $1)$. 
Table 1. Dune zone, floristic region, growth form and life span features of sand dune plant species in studied areas (Med: Mediterranean, Ir-Tr: Irano-Turanian, Eu-Sib: Euro-Siberian, Paleo Temp: Paleo Temporal, Sam: South America).

\begin{tabular}{|c|c|c|c|c|}
\hline Species & Zone & $\begin{array}{l}\text { Floristic } \\
\text { Region }\end{array}$ & $\begin{array}{l}\text { Growth } \\
\text { Form }\end{array}$ & $\begin{array}{l}\text { Life } \\
\text { Span }\end{array}$ \\
\hline Cakile maritima Scop. & A & Med & Herbaceous & Annual \\
\hline Calystegia soldanella (L.) R.Br. & A & - & Herbaceous & Perennial \\
\hline Digitaria ischaemum (Schreber ex Schweigger) Mühlenb. & A & - & Herbaceous & Annual \\
\hline Eryngium maritimum $\mathrm{L}$. & A & Med & Herbaceous & Perennial \\
\hline Euphorbia paralias $\mathrm{L}$. & A & Med & Herbaceous & Perennial \\
\hline Parapholis incurva (L.) C.E. Hubbard & A & - & Herbaceous & Annual \\
\hline Salsola ruthenica $\mathrm{L}$. & A & Paleo-Temp & Herbaceous & Annual \\
\hline Apocynum venetum L.subsp. sermatiense & A & Med & Herbaceous & Perennial \\
\hline Xanthium strumarium subsp. cavanillesii (Schouw) D.Löve \& Dans. & A & Ir-Tr & Herbaceous & Annual \\
\hline Tournefortia sibirica L.var. sibirica & A & Eu-Sib & Shrub & Perennial \\
\hline Achillea maritima (L.) Ehrend. \& Y.P. Guo subsp. maritima & B & Med & Herbaceous & Perennial \\
\hline Agrostis stolonifera $\mathrm{L}$. & B & Eu-Sib & Herbaceous & Perennial \\
\hline Ammophila arenaria (L.) Link subsp. arundinacea H. Lindb. Fil. & B & Med & Herbaceous & Perennial \\
\hline Crepis foetida L. subsp. rhoeadifolia (M.Bieb.) Čelak. & B & - & Herbaceous & Annual \\
\hline Cynanchum acutum L. subsp. acutum L. & B & Med & Herbaceous & Perennial \\
\hline Cynoglossum creticum Mill. & B & - & Herbaceous & Perennial \\
\hline $\begin{array}{l}\text { Elymus farctus (Viv.) Runemark ex Melderis subsp. bessarabicus (Savul. } \\
\text { et Rayss) Melderis var. bessarabicus }\end{array}$ & B & Med & Herbaceous & Perennial \\
\hline Glaucium flavum Crantz & B & - & Herbaceous & Perennial \\
\hline Gundelia tournefortii $\mathrm{L}$. & B & Ir-Tr & Herbaceous & Perennial \\
\hline Hypochoeris radicata $\mathrm{L}$. & B & Eu-Sib & Herbaceous & Perennial \\
\hline Juncus littoralis C.A. Meyer & B & Med & Herbaceous & Perennial \\
\hline Medicago marina $\mathrm{L}$. & B & - & Shrub & Perennial \\
\hline Medicago polymorpha L.var. polymorpha & B & - & Herbaceous & Annual \\
\hline Pancratium maritimum L. & $\mathrm{B}$ & Med & Herbaceous & Perennial \\
\hline Raphanus raphanistrum $\mathrm{L}$. & B & Med & Herbaceous & Annual \\
\hline Schoenoplectus triqueter $\mathrm{L}$. & B & - & Herbaceous & Perennial \\
\hline Scolymus hispanicus $\mathrm{L}$. & B & Med & Herbaceous & Perennial \\
\hline Stachys aпnиа L. (L.) subsp. аппиа var. аппиа & B & Med & Herbaceous & Perennial \\
\hline Centaurea iberica Trev. ex Sprengel & $\mathrm{C}$ & - & Herbaceous & Annual \\
\hline Cenchrus incertus M. A. Curtis & $\mathrm{C}$ & - & Herbaceous & Annual \\
\hline Cionura erecta $(\mathrm{L}$.$) Griseb.$ & $\mathrm{C}$ & Med & Shrub & Perennial \\
\hline Cyperus capitatus Vandelli & $\mathrm{C}$ & - & Herbaceous & Annual \\
\hline Echinops orientalis Trautv. & $\mathrm{C}$ & Ir-Tr & Herbaceous & Annual \\
\hline Euphorbia peplis L. & $\mathrm{C}$ & Med & Herbaceous & Annual \\
\hline Silene otites (L.) Wibel & $\mathrm{C}$ & - & Herbaceous & Annual \\
\hline Vulpia fasciculata (Forsskal) Fritsch & $\mathrm{C}$ & Med & Herbaceous & Annual \\
\hline Xanthium spinosum $\mathrm{L}$. & $\mathrm{C}$ & SAm & Herbaceous & Annual \\
\hline Crataegus monogyna Jacq. var. azarella & $\mathrm{D}$ & Paleo-Temp & Shrub & Perennial \\
\hline Eleagnus rhamnoides (L.) A. & $\mathrm{D}$ & - & Tree & Perennial \\
\hline Imperata cylindrica $(\mathrm{L}$.$) Raeusch.$ & $\mathrm{D}$ & - & Herbaceous & Perennial \\
\hline Medicago x varia Martyn & $\mathrm{D}$ & - & Herbaceous & Perennial \\
\hline Petrorhagia saxifraga (L.) Link & $\mathrm{D}$ & Eu-Sib & Herbaceous & Perennial \\
\hline Phleum exaratum Hochst. ex Griseb. subsp. exaratum & $\mathrm{D}$ & - & Herbaceous & Annual \\
\hline Teucrium chamaedrys L. subsp. chamaedrys & $\mathrm{D}$ & - & Herbaceous & Perennial \\
\hline Trifolium stellatum $\mathrm{L}$. & $\mathrm{D}$ & Med & Herbaceous & Annual \\
\hline Verbascum sinuatum L.var. sinuatum & $\mathrm{D}$ & Med & Herbaceous & Perennial \\
\hline Anagallis arvensis L.var. arvensis & $\mathrm{E}$ & Med & Herbaceous & Annual \\
\hline Anchusa hybrida Ten. & $\mathrm{E}$ & Med & Herbaceous & Perennial \\
\hline Bromus racemosus $\mathrm{L}$. & $\mathrm{E}$ & Eu-Sib & Herbaceous & Annual \\
\hline Cota tinctoria var. tinctoria $\mathrm{L}$. & E & - & Herbaceous & Perennial \\
\hline Daucus broteri Ten. & E & Med & Herbaceous & Annual \\
\hline Echium plantagineum $\mathrm{L}$. & $\mathrm{E}$ & - & Herbaceous & Annual \\
\hline Elymus elongatus (Host) Runemark subsp. elongatus & $\mathrm{E}$ & - & Herbaceous & Perennial \\
\hline Jurinea kilaea Azn. & E & Eu-Sib & Shrub & Perennial \\
\hline Kickxia commutata (Bernh. ex Reichb.) Fritsch subsp. commutata & $\mathrm{E}$ & Med & Herbaceous & Annual \\
\hline Lagurus ovatus L. & $\mathrm{E}$ & Med & Herbaceous & Annual \\
\hline Medicago littoralis Rohde ex Lois. var. littoralis & E & - & Herbaceous & Annual \\
\hline Plantago scabra Moench. & $\mathrm{E}$ & - & Herbaceous & Annual \\
\hline Polypogon monspeliensis L. (Desf.) & E & Med & Herbaceous & Annual \\
\hline Prunella vulgaris L. & $\mathrm{E}$ & Eu-Sib & Herbaceous & Perennial \\
\hline Satureja hortensis L. & E & - & Herbaceous & Annual \\
\hline Silene dichotoma Ehrh.var. dichotoma & E & Eu-Sib & Herbaceous & Annual \\
\hline Sophora alopecuroides L.var. alopecuroides & E & - & Herbaceous & Perennial \\
\hline Teucrium polium $\mathrm{L}$. & E & - & Herbaceous & Perennial \\
\hline Trifolium arvense L.var. arvense & E & Paleo-Temp & Herbaceous & Annual \\
\hline Trifolium resupinatum L.var. resupinatum & $\mathrm{E}$ & Med & Herbaceous & Annual \\
\hline
\end{tabular}


The rarity index of 67 species were calculated. According to the calculated rarity index the status of 47 species were determinated as moderate rarely and very rarely.

In upper beach or drift line dune zone, the rarity index of 4 species, Cakile maritima Scop., Parapholis incurva (L.) C.E. Hubbard, Apocynum venetum L. subsp. sermatiense, $T$. sibirica var. sibirica, are low. The rarity indexes of $T$. sibirica var. sibirica, $P$. incurva and $A$. venetum subsp. sermatiense is $\mathrm{Sj}<0.01$, while it is $0.01<\mathrm{Sj}<0.05$ for $C$. maritima (Table 2).
In embryonic or primary dune zone, the rarity index of $A$. stolonifera, Cynoglossum creticum Mill., G. tournefortii, Schoenoplectus triqueter L., Glaucium flavum Crantz, Raphanus raphanistrum L., Scolymus hispanicus L. is $\mathrm{Sj}<0.01$ while the index of Ammophila arenaria (L.) Link subsp. arundinacea H. Lindb. Fil., Cynanchum acutum L. subsp. acutum L., H. radicata, Medicago polymorpha L. var. polymorpha and Stachys annua L. (L.) subsp. annua var. annua is $0.01<\mathrm{Sj}<0.05$ (Table 2).

Table 2. Rarity indexes of sand dune plant species in studied areas.

\begin{tabular}{|c|c|c|c|c|c|c|c|}
\hline Species & & Zone & Rarity index & Species & & Zone & Rarity index \\
\hline C. maritima & $\mathrm{r}$ & A & 0.038 & C. monogyna var. azarella & $\mathrm{r}$ & $\mathrm{D}$ & 0.011 \\
\hline P. incurva & $\mathrm{rr}$ & A & 0.002 & I. cylindrica & $\mathrm{rr}$ & $\mathrm{D}$ & 0.001 \\
\hline A. venetum subsp. sermatiense & $\mathrm{rr}$ & $\mathrm{A}$ & 0.001 & M. $x$ varia & $\mathrm{r}$ & $\mathrm{D}$ & 0.011 \\
\hline T. sibirica var. sibirica & $\mathrm{rr}$ & $\mathrm{A}$ & 0.006 & P. saxifraga & $\mathrm{rr}$ & $\mathrm{D}$ & 0.003 \\
\hline A. stolonifera & $\mathrm{rr}$ & B & 0.001 & P. exaratum subsp. exaratum & $\mathrm{r}$ & $\mathrm{D}$ & 0.014 \\
\hline A. arenaria subsp. arundinacea & $\mathrm{r}$ & $\mathrm{B}$ & 0.042 & T. chamaedrys subsp. chamaedrys & $\mathrm{rr}$ & $\mathrm{D}$ & 0.005 \\
\hline C. acutum subsp. acutum & $\mathrm{r}$ & $\mathrm{B}$ & 0.029 & T. stellatum & $\mathrm{rr}$ & $\mathrm{D}$ & 0.001 \\
\hline C. creticum & $\mathrm{rr}$ & $\mathrm{B}$ & 0.001 & A. arvensis var. arvensis & $\mathrm{r}$ & $\mathrm{E}$ & 0.048 \\
\hline G. flavum & $\mathrm{rr}$ & $\mathrm{B}$ & 0.004 & A. hybrida & $\mathrm{rr}$ & $\mathrm{E}$ & 0.001 \\
\hline G. tournefortii & $\mathrm{rr}$ & B & 0.001 & B. racemosus & $\mathrm{r}$ & $\mathrm{E}$ & 0.042 \\
\hline H. radicata & $\mathrm{r}$ & $\mathrm{B}$ & 0.039 & E. plantagineum & $\mathrm{rr}$ & $\mathrm{E}$ & 0.002 \\
\hline M. polymorpha var. polymorpha & $\mathrm{r}$ & $\mathrm{B}$ & 0.019 & K. commutata subsp. commutata & $\mathrm{rr}$ & $\mathrm{E}$ & 0.002 \\
\hline$R$. raphanistrum & $\mathrm{rr}$ & $\mathrm{B}$ & 0.001 & L. ovatus & $\mathrm{r}$ & $\mathrm{E}$ & 0.015 \\
\hline S. triqueter & $\mathrm{rr}$ & $\mathrm{B}$ & 0.001 & M. littoralis var. littoralis & $\mathrm{rr}$ & $\mathrm{E}$ & 0.001 \\
\hline S. hispanicus & $\mathrm{rr}$ & B & 0.001 & P. scabra & $\mathrm{rr}$ & $\mathrm{E}$ & 0.002 \\
\hline S. annua subsp. annua var. аппиа & $\mathrm{r}$ & $\mathrm{B}$ & 0.021 & P. monspeliensis & $\mathrm{rr}$ & $\mathrm{E}$ & 0.001 \\
\hline C. iberica & $\mathrm{rr}$ & $\overline{\mathrm{C}}$ & 0.001 & P. vulgaris & $\mathrm{rr}$ & $\mathrm{E}$ & 0.003 \\
\hline C. incertus & $\mathrm{rr}$ & $\mathrm{C}$ & 0.001 & S. hortensis & $\mathrm{r}$ & $\mathrm{E}$ & 0.025 \\
\hline C. erecta & $\mathrm{r}$ & $\mathrm{C}$ & 0.019 & S. dichotoma var. dichotoma & $\mathrm{r}$ & $\mathrm{E}$ & 0.047 \\
\hline E. orientalis & $\mathrm{rr}$ & $\mathrm{C}$ & 0.001 & S. alopecuroides var. alopecuroides & $\mathrm{r}$ & $\mathrm{E}$ & 0.018 \\
\hline E. peplis & $\mathrm{rr}$ & $\mathrm{C}$ & 0.007 & T. polium & $\mathrm{r}$ & $\mathrm{E}$ & 0.019 \\
\hline S. otites & $\mathrm{rr}$ & $\mathrm{C}$ & 0.001 & T. arvense var. arvense & $\mathrm{rr}$ & $\mathrm{E}$ & 0.001 \\
\hline V. fasciculata & $\mathrm{rr}$ & $\mathrm{C}$ & 0.001 & T. resupinatum var. resupinatum & $\mathrm{rr}$ & $\mathrm{E}$ & 0.001 \\
\hline$X$. spinosum & $\mathrm{rr}$ & $\mathrm{C}$ & 0.001 & & & & \\
\hline
\end{tabular}

In the main dune zone, the rarity indexes of Centaurea iberica Trev. ex Sprengel, Cenchrus incertus M. A. Curtis, E. orientalis, E. peplis, Silene otites (L.) Wibel, V. fasciculata, and X. spinosum was calculated under 0.01 while it is between 0.01 and 0.05 for C. erecta (Table 2).

In transitional dune zone, Imperata cylindrica (L.) Raeusch., Petrorhagia saxifraga (L.) Link, Teucrium chamaedrys L. subsp. chamaedrys and Trifolium stellatum L. rarity indexes were under 0.01 value. Phleum exaratum Hochst. ex Griseb. subsp. exaratum, Medicago x varia Martyn, and Crataegus monogyna Jacq. var. azarella were between 0.01 and 0.05 (Table 2).

Finally, in fixed dune zone, 16 species were found moderately rare, and very rarely status considering calculated indexes. The rarity indexes of Anagallis arvensis L. var. arvensis, Bromus racemosus L., Lagurus ovatus L., Satureja hortensis L., Silene dichotoma Ehrh. var. dichotoma, Sophora alopecuroides L. var. alopecuroides and Teucrium polium $\mathrm{L}$. is $0.01<\mathrm{Sj}<0.05$
(Table 2) while it is $\mathrm{Sj}<0.01$ for Kickxia commutata (Bernh. ex Reichb.) Fritsch subsp. commutata, Plantago scabra Moench, Prunella vulgaris L., Trifolium resupinatum L. var. resupinatum, Anchusa hybrida Ten., Echium plantagineum L., Medicago littoralis Rohde ex Lois. var. littoralis, Polypogon monspeliensis L. (Desf.), T. arvense var. arvense.

\section{Discussions}

As reported in previous researches performed on Mediterranean coastal dunes (Acosta et al., 2009), species diversity on Black Sea district tends to increase with the distance from the shoreline. The results of this study, which shows a gradualy increase in terms of the number of the species from seashore to internal parts of the dune zone, is compatible with the resarches mentioned above.

A few plant species can survive in harsh ecological conditions such as high salinity, unstable substrate, wave effect etc. This is the reason of the low number of species 
in the places close to the sea at dune zones. In drift line zone, not only these harsh factors but also the activities such as agriculture, tourism, trampling, construction of houses and roads, waste disposal, and plantation of trees and shrubs (Agir et al., 2014) also have a negative role on the plant species richness. As a result of the factors mentioned above in driftline dune zone, the number of the character species are very few. In this study, only $C$. maritima, $P$. incurva, A. venetum subsp. sermatiense and T. sibirica var. sibirica determined as the character species for the drift line zone. Primary dune (or embryonic) zone also has low plant biodiversity. Species in this zone can resist to deep sand burial, and they are an important impeding factor for the movement of sand which is forced by the sea winds (Attorre et al., 2013; Agir et al., 2014). The rarity index values of the species in the primary/embryonic dune zone is low. Especially, the rarity indexes of $A$. stolonifera, $C$. creticum, $G$. tournefortii, S. triqueter, G. flavum, R. raphanistrum, $S$. hispanicus are the lowest. Achillea maritima which is important for the stability of dune zones (Honrado et al., 2010; Agir et al., 2014) and which is is also a character species of this zone is also rare.

Almost all species in the main dune zone are rare because this zone has similar properties with primary dune zone. In this zone, plant communities tend to be permanent and less exposed to harsh conditions (Maun, 2009; Acosta et al., 2007, 2009; Attorre et al., 2013), but it was exposed to the high disturbance regarding salt spray, dune movement, and tourism activities. So plant density and diversity gradually decreases.

The rarity index values of species of transitional and fixed dune zones are low. These two zones include more exclusive species (i.e., Euphorbia terracina L., Jurinea kilea Azn.) than the other zones (Acosta et al., 2009). It is known that inundation has a pronounced regulatory effect on the distribution and abundance of plant species (Deegan and Harrington, 2004).

It is found that density and number of dune plant species are gradually decreasing. The coastal dune species in the Central Black Sea Region have been affected by the disturbance factors such as wave action, dense tourism activities, sand extraction, etc.. Extreme physical stress and disturbance factors act shaping community zonation even at very small spatial scales in coastal dune ecosystems (Carboni et al., 2010). Sustainable management programmes in coastal sand dunes should be included in the conservation of species poor-habitats containing unique or endangered species elements (Acosta et al., 2009).

\section{References}

Acosta A, Carranza ML, Izzi CF (2005). Combining land cover mapping of coastal dunes with vegetation analysis. Applied Vegetation Science 8: 133-138.

Acosta A, Carranza ML, Izzi CF (2009). Are there habitats that contribute best to plant species diversity in coastal dunes? Biodiversity and Conservation 18: 1087-1098.

Acosta A, Ercole S, Stanisci A, Depatta V, Blasi C (2007). Coastal vegetation zonation and dune morphology in some Mediterranean ecosystems. Journal of Coastal Research 23: 1518-1524.

Agır SU, Kutbay HG, Karaer F, Surmen B (2014). The classification of coastal dune vegetation in Central Black Sea Region of Turkey by numerical methods and EU habitat types. Rendiconti Lincei - Scienze Fisiche e Naturali 25(4): 453-460.

Agır SU, Kutbay HG, Surmen B (2016a). Plant diversity along coastal dunes of the Black Sea (North of Turkey). Rendiconti Lincei - Scienze Fisiche e Naturali 27(3): 443-453.

Agır SU, Kutbay HG, Surmen B (2016b). Species co-occurence in coastal dunes in North of Turkey. Rendiconti Lincei - Scienze Fisiche e Naturali 27(4): 729-736.

Agir SU, Kutbay HG, Surmen B, Elmas E (2017). The effects of erosion and accretion on plant communities in coastal dunes in north of Turkey. Rendiconti Lincei - Scienze Fisiche e Naturali 28(1): 203-224.

Attorre F, Maggini A, Di Traglia M, De Sanctis M, Vitale M (2013). A methodological approach for assessing the effects of disturbance factors on the conservation status of Mediterranean coastal dune systems. Applied Vegetation Science 16: $333-342$.

Braun-Blanquet J (1964). Pflanzensoziologie: Grundzuge der Vegetationskunde. Vienna: Springer.

Carboni M, Carranza ML, Acosta A (2009). Assessing conservation status on coastal dunes: a multiscale approach. Landscape and Urban Planning 91: 17-25.

Carranza ML, Acosta ATR, Stanisci A, Pirone G, Ciaschetti G (2008). Ecosystem classification for EU habitat distribution assessment in sandy coastal environments: an application in central Italy. Environmental Monitoring and Assessment 140: 99-107.

De Lillis M, Costanzo L, Bianco PM, Tinelli A (2004). Sustainability of sand dune restoration along the coast of the Tyrrhenian Sea. Journal of Coastal Conservation 10(1): 93-100.

Deegan BM, Harrington TJ (2004). The distribution and ecology of Schoenoplectus triqueter in the Shannon Estuary. In: Biology and Environment: Proceedings of the Royal Irish Academy. JSTOR pp 107-117.

Fenu G, Cogoni D, Ferrara C, Pinna MS, Bacchetta G (2012). Relationships between coastal sand dune properties and plant community distribution: the case of Is Arenas (Sardinia). Plant Biosystems-An International Journal Dealing with all Aspects of Plant Biology 146(3): 586-602. 
Guner A, Aslan S, Ekim T, Vural M, Babac MT (2012). A checklist of the Flora of Turkey (vascular plants). İstanbul: Publications of Nezahat Gokyigit Botanical Garden.

Honrado J, Vicente J, Lomba A, Alves P, Macedo JA, Henriques R, Granja H, Caldas FB (2010). Fine-scale patterns of vegetation assembly in the monitoring of changes in coastal sand-dune landscapes. Web Ecology 10: 1-14.

Kutbay HG, Sürmen B, Ağır ŞU, Kılıç DD (2017). Samsun ili kıyı kumullarında tespit edilen yabancı bitkiler. Turkish Journal of Weed Science 20(2): 19-27.

Maun MA (2009). The biology of coastal sand dunes. Oxford: Oxford University Press.

Miller TE, Gornish ES, Buckley HL (2010). Climate and coastal dune vegetation: disturbance, recovery, and succession. Plant Ecology 206(1): 97-104.

Prisco I, Acosta ATR, Ercole S (2012). An overview of the Italian coastal dune EU habitats. Annali di Botanica (Roma) 2:39-48.

Spanou S, Verroios G, Dimitrellos G, Tiniakou A, Georgiadis T (2006). Notes on flora and vegetation of the sand dunes of Western Greece. Willdenowia 36(1): 235-246.

Stancheva M, Ratas U, Orviku K, Palazov A, Rivis R, Kont A, Peychev V, Tonisson T, Stanchev H (2011). Sand dune destruction due to increased human impacts along the Bulgarian Black Sea and Estonian Baltic Sea Coasts. Journal of Coastal Research 64: 324-328.

Cite this article: Sürmen B, Ulu Ağır Ş, Kutbay HG (2019). Rare dune plant species in Samsun Province, Turkey. Anatolian Journal of Botany 3(2): 34-39. 